\title{
Tax Case: Single Member LLC Brings In A Second Owner
}

\author{
Monique O. Durant, JD, CPA, LLM, Central Connecticut State University, USA
}

\begin{abstract}
This paper presents a tax case simulating a real-world experience whereby a single member limited liability company that is currently classified as a disregarded entity, takes on a second owner. By default the entity will be classified as a partnership; however, if an affirmative election is made, the LLC could be taxed as a corporation or as an S corporation. Students are presented with two options for partnership formation along with hypothetical data and business objectives of the partners. They are then asked to consider the tax rules of two options, along with the resulting tax and economic impact of each option, in order to make a recommendation about the more favorable business alternative. Students are also asked to consider alternate forms of entity in addition to that of a partnership and the potential impact on the owners. In order to do this, students rely on fundamental knowledge learned in the typical business entities tax course and use their research and analytical skills to synthesize the most favorable outcome.

Students are asked to deliver a tax memorandum which addresses a series of issues or questions, plus a client letter discussing the tax considerations as well as non-tax factors, in addition to Excel worksheets which outline the tax impact under each of the two options provided. As a result of this assignment, students discover the value of prudent and skillful tax planning, that additional, non-tax factors may need to be considered, and the positive impact they can have on the financial affairs of their clients.
\end{abstract}

Keywords: Tax Case: Single Member LLC Brings in a Second Owner

\section{INTRODUCTION}

\section{Students research an open transaction}

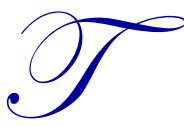

his paper presents a basic tax case simulating a real-world experience in the area of partnership taxation. Students are presented with hypothetical data and business objectives of the current and prospective members, and are asked to formulate the best outcome to meet the business objectives.

\section{Summary of the fact pattern}

The fact pattern addresses a common issue that most practicing CPAs will address in their career but may not be completely addressed in partnership formation materials of current tax textbooks: The owner of a singlemember limited liability company wants to take on a business partner. Students are asked to assess two options: (1) the new member purchases a 50\% interest in the LLC directly from the original member, or (2) the new member contributes cash to the LLC in exchange for a 50\% interest in the LLC. The options, benign in appearance, differ substantially in their impact on tax basis of the business assets, recognition of taxable gain on the existing member, and life of the business.

\section{Students rely on partnership formation rules}

In order to complete the assignment, students rely on knowledge learned in the typical business entity taxation course, and they practice research and analytical skills to synthesize the most favorable outcome. In doing 
so, students will consider the partnership formation rules and compare the impact of each option on the business and its partners or members. Students are also asked to contemplate other entity options for the business.

\section{Teaching objectives}

Students are asked to deliver a tax memorandum which addresses a series of issues, as well as a client letter and Excel worksheet which presents the tax impact under each of the two options mentioned above. It is anticipated that as a result of this assignment, students will discover the practical application of the partnership formation rules as well as the benefit of prudent and skillful tax planning on business owners.

\section{Intended audience}

This case was designed for students in an undergraduate business entities course. However, this case would be equally effective in a master's program course in business entity taxation or in a tax research class by instructors that want to challenge the students to work independently on a tax case. Ideally, students have already acquired some experience in research and writing in the discipline of taxation, and have an interest in taxation as a practice area.

\section{Placement in the curriculum}

Best placement for this case would be in tandem with materials on partnership formation, and serves as a good introductory tax research assignment.

\section{Necessary resources}

Students will require access to a standard online tax research tool (e.g., RIA-Checkpoint or CCHIntelliconnect), or to paper-based research tools in order to complete the assignment.

\section{Estimated in-class time commitment}

In-class time to review the fact pattern and assign the project is approximately $15-20$ minutes; time to review or 'de-brief' on the due date (to review the balance sheet under each of the options and to compare the results) is approximately 30 minutes. Additional time would be required to explain the design of a tax memorandum if students have not already completed such assignments. Students reported a range of five to eight hours to complete the assignment.

\section{Experiential outcome}

This case was effectively assigned to two sections of students in a business entities course. Based on classroom discussion and grades of the papers, the assignment objectives were met. Among twenty-seven students in one section and fourteen in another, $50 \%$ received a grade of "B" or better. The average score of 85 seems reasonable, considering that nearly all students were undergraduate seniors and the course is an elective.

\section{Result}

This is an effective basic or introductory research assignment for students in a taxation of business entities course. Appropriate placement for this assignment would be in tandem with materials on partnership formation. During completion of this assignment, students will have gained a greater insight into the benefits of tax planning to clients, and they will improve their sense of the reward that prudent tax planning has on the lives of a small business and its owners. 


\section{THE CASE}

\section{Silver Streak, LLC - Single Member LLC Brings in a Second Owner A Case for Partnership Formation}

Steve Silver currently operates a dry cleaning business. A few years ago, Steve set up a single member (i.e., one owner) limited liability company, which is permissible in his state. With the help of his attorney he organized the business as "Silver Streak Dry Cleaning, LLC."

Steve's business has been profitable, and his immediate goal is to open one or more additional dry cleaning locations to increase total profits. Steve also has other business interests, including owning residential rental property that demands a portion of his time. Steve would like to build co-management of Silver Streak to the point that he no longer needs to participate in the day-to-day management of the dry cleaning business. His goal is to "cash out" and retire in 10-15 years. The profits of Silver Streak until his retirement, along with proceeds from the eventual sale of his ownership interest in Silver Streak near his retirement, will help provide the wealth he will need during retirement.

As a first step toward these goals, Steve wants to bring Gary Gold "into the business." After Gary buys partial ownership in the business it will be a two-member LLC which, by default, will be taxed as a partnership. Gary operated a similar dry cleaning business in a neighboring state for several years. Gary recently sold his business and moved to Steve's state for personal reasons. Steve and Gary are not related. Steve and Gary agree that the fair market value (FMV) of Silver Streak, LLC is $\$ 800,000$, which is $\$ 100,000$ greater than the $\$ 700,000$ book value of the assets of the business under GAAP.

You are Steve's tax consultant and you told Steve there are two primary options available. Steve sets up a meeting with you to understand more about these two options and get your recommendation as to which option he should choose.

The two options are as follows:

Option 1. Gary could purchase a 50\% interest in Silver Streak, LLC from Steve for $\$ 400,000$. Steve does not contribute any portion of the $\$ 400,000$ received from Gary to the LLC. Gary could use the $\$ 400,000$ received, net of taxes, to augment his other business activities or to invest. Steve and Gary operate the business as co-owners.

Option 2. Gary could contribute $\$ 800,000$ cash to the LLC in exchange for a $50 \%$ interest in the LLC. The coowners agree to use the contributed cash to purchase new assets and expand into a second store. Steve and Gary operate the business as co-owners.

The balance sheet for Silver Streak for December 31, 2011 is below. Assume there will be no change in FMV of any balance sheet item from December 31, 2011 until the date this transaction is completed.

\begin{tabular}{|c|c|c|c|c|c|c|}
\hline \multicolumn{7}{|c|}{$\begin{array}{c}\text { Silver Streak, LLC } \\
\text { Balance Sheet } \\
\text { As at December 31, } 2011\end{array}$} \\
\hline & & FMV & & Books & & Tax Basis \\
\hline \multicolumn{7}{|l|}{ Assets } \\
\hline$\overline{C a s h}$ & $\$$ & 25,000 & $\$$ & 25,000 & $\$$ & 25,000 \\
\hline Equipment & & 145,000 & & 125,000 & & 125,000 \\
\hline Building & & 320,000 & & 250,000 & & 250,000 \\
\hline Land & & 310,000 & & 300,000 & & 300,000 \\
\hline Total & $\$$ & 800,000 & $\$$ & 700,000 & $\$$ & 700,000 \\
\hline \multicolumn{7}{|l|}{ Liabilities and Capital } \\
\hline Capital, Steve & $\$$ & 800,000 & $\$$ & 700,000 & $\$$ & 700,000 \\
\hline Total & $\$$ & 800,000 & $\$$ & 700,000 & $\$$ & 700,000 \\
\hline
\end{tabular}


I. Issues:

A. What is Silver Streak's current tax status (classification)? What forms and schedules are currently used to file Silver Streak's federal tax return?

B. What will be Silver Streak's tax status after the transaction under the scenarios listed above?

C. What are the federal income tax consequences to Steve with each of the options mentioned above? Compare in detail the nature of the tax consequences (in terms of amount, character of income and holding period.)

D. Is an election available to Silver Streak such that the LLC will be classified as an association (and therefore taxed as a corporation)? or an S corporation? If the answer to either possibility is "yes," how would they go about making such an election?

E. What result would occur if Silver Streak elects to be taxed as an association? What would be the tax result to Steve and Gary? Consider the reasons that such an election might be advantageous.

F. Advise Steve as to the relative advantages and disadvantages to him of the two options. Discuss the possible tax and non-tax factors under which Steve might prefer one option over the other.

G. Alternatively, advise Gary as to the relative advantages and disadvantages of the two options, considering the tax and non-tax factors under which Gary might prefer one of the two options.

H. How would your suggestion in $(\mathrm{F})$ change if Steve is considering "cashing out" some of the value of his business now, rather than in $10-15$ years? For instance, Steve may believe that if the $\$ 400,000$ sales proceeds from Option 1 are invested conservatively; (even if the option would trigger a tax liability for him) this would reduce his investment risk, which is important for improving the security of wealth needed for retirement in the future.

II. Prepare a tax memorandum addressing the issues above and which should be no more than five pages in length, single-spaced; containing the following sections: Facts, Issues, Conclusion, and Discussion. Include cited footnotes to primary authorities.

III. Next, prepare a letter to Steve Silver, addressing the issues in normal business language, explaining the advantages and disadvantages to the two options, the expected tax cost of those options and a recommendation of one of the options so that Steve can make the final decision. The client letter should be no more than two single-spaced pages in length.

IV. As backup to the client letter, prepare and attach Excel spreadsheets with the following:

A. Calculate the Balance Sheet as it exists on December 31, 2011 under options 1 and 2 discussed above in (C), remembering to present columns for FMV, Books, and Tax Basis; and

B. Calculate the tax impact to Steve and Gary under the option discussed in (E) above.

V. Attach printouts of the authorities upon which you relied on in preparing the memorandum.

VI. You may wish to begin your research with the following research aids:

A. Revenue Ruling 99-5, 1999-1 CB 434, 1/15/1999.

B. IRS Publication 3402 - March 2010: LLCs Classified as Disregarded Entities. 


\section{TEACHING NOTES}

I. Issues:

\section{Silver Streak - Single Member LLC Brings in a Second Owner A Case in Partnership Formation Teaching Notes}

A. What is Silver Streak's current tax status (classification)? What IRS tax forms and schedules are currently used to file Silver Streak's federal tax return?

If an LLC has only one member and has not elected to be treated otherwise, it is classified as a disregarded entity. ${ }^{1}$ As a result, its income, deductions, gains, losses, and credits are reported on the owner's income tax return. Because the owner of the LLC is an individual, the LLC's income and deductions would be reported on Schedule C, Profit or Loss from Business (Sole Proprietorship) that is attached to the individual owner's Form 1040. If Silver Streak had been a farm, Schedule F, Profit or Loss from Farming, would be filed instead of Schedule C. If the business had rental real estate income or royalty income, Schedule E, Supplemental Income and Loss, would be filed instead of, or in addition to, Schedule C. Since Silver Streak will not report rental real estate income or royalty income (Schedule E), and is not in the business of farming (Schedule F), and the business will be too complex to use Schedule C-EZ, in all likelihood the appropriate form will be Schedule C.

B. What will be Silver Streak's tax status after the transaction under each of the scenarios listed above?

When a disregarded entity with one member receives another member, by default it is classified as a partnership. ${ }^{2}$ Whether Gary purchases a 50\% interest in Silver Streak (Option 1) or he contributes cash to the LLC in exchange for a 50\% interest in the LLC (Option 2), Silver Streak will have a second member and as a result Silver Streak will be taxed as a partnership unless an election to be taxed otherwise is made (discussed in D. below).

C. What are the federal income tax consequences to Steve with each of the options mentioned above? Compare in detail the nature of the tax consequences (in terms of amount, character of income and holding period.)

1. Option 1 - Gary purchases a 50\% interest in the LLC from Steve for $\$ 400,000 .^{3}$

a. If Gary purchases $50 \%$ of Steve's interest in the disregarded entity the transaction is treated as a purchase of 50\% of each of the LLC's assets, which have been deemed as held directly by Steve for federal tax purposes. ${ }^{4}$ Immediately thereafter, both members are treated as contributing their respective interests in those assets to a partnership in exchange for ownership interests in the partnership.

b. Under IRC $\S 1001$, the original member recognizes gain or loss from the deemed sale of the $50 \%$ interest in each assets of the LLC to the second member. Steve recognizes $\$ 50,000$ of taxable gain (i.e., $\$ 400,000$ realized on the sale minus $\$ 350,000$ (1/2 of the tax basis). (See the Excel spreadsheet included in these materials for more detail.)

c. Under IRC $\$ 721(\mathrm{a})$, no gain or loss is recognized by either member as a result of the conversion of the disregarded entity to a partnership.

\footnotetext{
${ }^{1}$ Regs. \$301.7701-3(e).

${ }^{2}$ Rev. Rul. 99-5, 1999-1 CB 434.

${ }^{3}$ The substance of the discussion in Section $\mathrm{C}$ is summarized on pages 12 and 13 below.

${ }^{4}$ Id.
} 
d. Under IRC $\S 722$, Gary's tax basis in the partnership interest is equal to the purchase price paid. The original member's basis in the partnership interest is equal to his or her $50 \%$ share of the assets of the LLC. Gary's outside basis is $\$ 400,000$; Steve's outside basis is $\$ 350,000$.

e. Under IRC $\S 723$, the basis of the property deemed contributed to the partnership by both members is the adjusted basis of that property in each member's hands immediately after the deemed sale. Silver Streak's total inside basis of the property is now $\$ 750,000$ (Gary's $\$ 400,000$ plus Steve's $\$ 350,000)$.

f. Under IRC $\S 1223(\mathrm{a})$ the original member's holding period for the partnership interest received includes his or her holding period in the capital assets and $\$ 1231$ business assets held by the LLC when it converted from a disregarded entity to a partnership. The second member's holding period for the partnership interest begins on the day following the date of purchase of the LLC interest. ${ }^{5}$ Steve's holding period began from the original purchase date of each of the business assets; Gary's holding period began on the day after he purchased the $50 \%$ interest in the LLC.

2. Option 2-Gary contributes cash to the LLC in exchange for a $50 \%$ interest in the LLC.

a. When a second member contributes cash to the LLC, the LLC is converted from a disregarded entity to a partnership. ${ }^{6}$ Gary makes a contribution of $\$ 800,000$ to Silver Streak in exchange for his interest in the partnership, and Steve is treated as having contributed all of the assets, with tax basis of $\$ 700,000$, to the partnership in exchange for his partnership interest.

b. Gary's contribution is treated as a contribution to a partnership in exchange for an ownership interest in the partnership, and the original member is treated as having contributed all the assets of the LLC to the partnership in exchange for a partnership interest. ${ }^{7}$

c. Under IRC $\$ 721(a)$, no gain or loss is recognized by either member as a result of the conversion of the disregarded entity to a partnership. Neither Steve nor Gary recognizes any gain or loss as a consequence of this transaction.

d. Under IRC $\S 722$, the original member's basis in the partnership interest is equal to that member's basis in the assets of the LLC which he or she is deemed to have contributed to the newly formed partnership. Gary's basis in his partnership interest is $\$ 800,000$, the amount of his contribution in exchange for the partnership interest. Steve's outside basis in his partnership interest is $\$ 700,000$, the same amount as his basis in the assets deemed contributed to the partnership.

e. Under $\$ 723$, the inside basis that Silver Streak has in the property contributed by the original member is the adjusted basis of that property in Steve's hands. The basis of the property contributed to the partnership by the second member, Gary, is the amount of cash contributed to the partnership. Total basis in partnership assets becomes $\$ 1,500,000$, the sum of Steve's outside basis of $\$ 700,000$ in the assets he contributed plus Gary's contribution of $\$ 800,000$.

f. Under §1223(1), Steve's holding period for the partnership interest received includes the holding period in the capital and $\S 1231$ assets deemed contributed when the disregarded entity converted to a partnership. Because Gary contributed cash rather than property, his holding period for the partnership interest begins on the day following the date of that member's contribution to the LLC.

g. Under $§ 1223(2)$, the partnership's holding period for the assets transferred to it includes the original member's holding period. Steve's holding period for his partnership interest will include the original holding period in the assets he contributed.

\footnotetext{
${ }_{6}^{5}$ Rev. Rul. 99-5, 1999-1 CB 434.

${ }^{6} \mathrm{Id}$.

${ }^{7} I d$. 
D. Is an election available for Silver Streak such that the LLC is taxed as a association (and therefore taxed as a corporation)? or an S corporation? If the answer to either possibility is "yes," how would they go about making such an election?

The LLC, now that it has two members (i.e., owners), receives the default classification of a partnership. It may elect to be classified as an "association," which is taxable as a corporation. ${ }^{8}$ For the LLC to be taxed as a corporation it must make a so called "check the box election" by filing an Entity Classification Election (Form 8832). ${ }^{9}$ Once its classification election is effective, an LLC cannot change its classification during the following 60 months. ${ }^{10}$ An alternative to being taxed as a corporation is, since all of the eligibility criteria appear to be met, for Silver Streak to file an election to be an S Corporation (Form 2553). ${ }^{11}$

E. What result would occur if Silver Streak elects to be taxed as an association? What would be the tax result to Steve and Gary? Consider the reasons that such an election might be advantageous.

A partnership that makes an election to be treated as an association is deemed to contribute all its assets and liabilities to the new association in exchange for stock in that association. ${ }^{12}$ This contribution of all assets and liabilities to the newly created corporation will not result in any gain or loss to the Steve on the exchange. ${ }^{13}$ Immediately thereafter the partnership liquidates by distributing the stock of the association to its partners. These deemed transactions are treated as occurring immediately before the close of the day before the election is effective. ${ }^{14}$

There are few instances in which an association would be more advantageous than a limited liability company. An LLC, like a corporation, offers the non-tax advantage of insulating its owners from personal liability; at the same time, it can elect to be treated for tax purposes as a partnership, thus avoiding double taxation. However, one non-tax advantage is that limited liability companies are creatures of state law and thus given to the inconsistencies between states; if the business wishes to begin operations in another state, it may be easier to do so in the corporate form.

F. Advise Steve as to the relative advantages and disadvantages to him of the two options. Discuss the possible tax and non-tax factors under which Steve might prefer one option over the other.

1. The net impact of Option 1 on the facts of Silver Streak is that, as a result of the deemed sale of the $50 \%$ interest in each of the assets of the LLC in (b) above, Steve recognizes $\$ 50,000$ of taxable gain on the transaction(see Excel worksheets below). Note that Option 1 provides partial "cash out" to Steve currently and will not further his immediate goal to open one or more additional dry cleaning locations in order to increase profits, since the cash will not be available in the business to purchase more assets.

2. The net impact of Option 2 on the facts of Silver Streak is that Gary becomes the second member of the LLC in a tax-free exchange. Neither Steve or Gary recognize gain on the transaction (see worksheets below) and Gary's contribution of $\$ 800,000$ furthers the business goals of opening additional stores which could potentially increase profitability, since $\$ 800,000$ of additional tax free cash will provide for purchase of additional business assets.

3. Therefore, Option 2 meets Steve's goals of expanding the business and an additional advantage is that it provides a tax-free transaction.

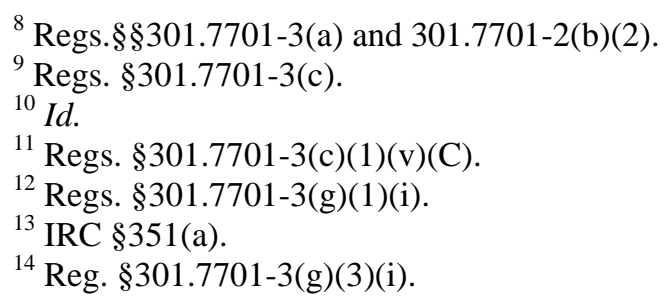


G. Alternative, advise Gary as to the relative advantages and disadvantages of the two options, considering the tax and non-tax factors under which Gary might prefer one of the two options.

1. Option 1 will not produce an immediate taxable impact to Gary, but will produce a "step-up" for his half of each asset to one half of fair market value. (see Excel worksheet below) A major non-tax disadvantage of this option for Gary is that profits of the business must be shared between Steve and Gary which may not meet the expectations of either owner.

2. Option 2 will not produce the "step up" in basis for Gary that would occur in Option 1, since his contribution would be entirely cash. Additionally, this option will require that Gary contribute $\$ 800,000$ to the business rather than $\$ 400,000$, which may not be as realistic for him. However, as with Steve, the infusion of this much cash would allow for the purchase of additional assets to enhance profits, which is the intent of both owners.

H. Would your suggestion in (F) change if Steve is considering "cashing out" some of the value of his business now, rather than in $10-15$ years? For instance, Steve may believe that if the $\$ 400,000$ sales proceeds from Option 1 are invested conservatively; (even if the option would trigger a tax liability for him) this would reduce his investment risk, which is important for improving the security of wealth needed for retirement in the future.

If Steve wants cash presently, he may wish to choose Option 1, rather than Option 2, which would put $\$ 400,000$ in his pocket immediately. The taxable gain on the sale would be $\$ 50,000$, some portion of which is susceptible to capital gains and some to ordinary rates (see Excel spreadsheet below), however the net after-tax proceeds would produce much of the security he needs for retirement.

Note: Calculations of the Balance Sheet under options 1 and 2, as well as the tax impact to Steve and Gary are included in the Excel Spreadsheet at the end of this case. 
Comparison of Options

\begin{tabular}{|c|c|c|}
\hline & Option 1 - Sale of $50 \%$ of Ownership by Old Member & Option 2 - Contribution by New Member to the LLC \\
\hline $\begin{array}{l}\text { Description of } \\
\text { transaction }\end{array}$ & $\begin{array}{l}\text { Steve sells } 50 \% \text { ownership interest in the single member } \\
\text { LLC (a disregarded entity) to Gary. }\end{array}$ & $\begin{array}{l}\text { Gary contributes cash to the LLC in exchange for a } 50 \% \\
\text { ownership interest in the LLC. }\end{array}$ \\
\hline $\begin{array}{l}\text { Taxability of } \\
\text { the } \\
\text { transaction. }\end{array}$ & $\begin{array}{l}\text { Taxable exchange. Gain or loss from the sale of } 50 \% \\
\text { interest in assets is the difference between the amount } \\
\text { realized and the adjusted basis in Section } 1011 \text {. Section } \\
\text { 1001(a). Note that because Steve is viewed has having } \\
\text { separate ownership interest in the LLC, at this point he is } \\
\text { seen as having a separate basis and holding period in each } \\
\text { of the business assets. The character of the gain or loss on } \\
\text { the sale of 50\% to Gary may be capital or ordinary for the } \\
\text { sale of each asset, and may include the recognition of } \\
\text { recaptured depreciation, as with the sale of any separately- } \\
\text { owned assets. }\end{array}$ & $\begin{array}{l}\text { Non-Taxable exchange. No gain or loss recognized to } \\
\text { the partnership or to any partner under Section } 721 \text { (a). }\end{array}$ \\
\hline $\begin{array}{l}\text { Impact to } \\
\text { Steve as } \\
\text { original } \\
\text { member }\end{array}$ & $\begin{array}{l}\text { Steve, as a single member, is seen for tax purposes as the } \\
\text { direct owner of all of the LLC assets Steve is not seen as } \\
\text { having a separate ownership interest in the entity, with a } \\
\text { separate basis or a separate holding period. When Gary } \\
\text { becomes an additional owner, a tax partnership is created } \\
\text { and that tax partnership becomes the deemed owner of the } \\
\text { LLC assets. Rev. Rul. 99-5. }\end{array}$ & $\begin{array}{l}\text { Non-recognition event for Steve under Section } 721(\mathrm{a}) \text {. } \\
\text { He recognizes no gain or loss from the deemed } \\
\text { contribution of assets. Steve is treated as the direct } \\
\text { owner of all the assets of the previously disregarded } \\
\text { entity and is treated as contributing all those assets to the } \\
\text { newly created partnership in exchange for an LLC } \\
\text { membership interest. Rev. Rul. 99-5. }\end{array}$ \\
\hline $\begin{array}{l}\text { Impact to } \\
\text { Gary as new } \\
\text { member }\end{array}$ & $\begin{array}{l}\text { Gary's purchase of } 50 \% \text { of Steve's membership interest in } \\
\text { the LLC is seen as Gary's purchase of a } 50 \% \text { interest in } \\
\text { each of the company's assets. Rev. Rul. 99-5. }\end{array}$ & $\begin{array}{l}\text { Gary is treated as contributing } \$ 800,000 \text { in cash for his } \\
50 \% \text { interest. Rev. Rul. } 99-5 \text {. }\end{array}$ \\
\hline $\begin{array}{l}\text { Contributions } \\
\text { to the new tax } \\
\text { partnership }\end{array}$ & $\begin{array}{l}\text { Steve and Gary are deemed to have immediately } \\
\text { contributed their interests in these assets to the new tax } \\
\text { partnership in exchange for membership interests in that } \\
\text { partnership. Rev. Rul. } 99-5 \text {. }\end{array}$ & $\begin{array}{l}\text { Steve and Gary are treated as contributing assets in } \\
\text { exchange for their respective interests in the newly } \\
\text { created tax partnership. Rev. Rul. 99-5. }\end{array}$ \\
\hline $\begin{array}{l}\text { Gary's cash } \\
\text { investment }\end{array}$ & $\$ 400,000$ & $\$ 800,000$ \\
\hline $\begin{array}{l}\text { Disposition of } \\
\text { Gary's cash } \\
\text { investment }\end{array}$ & No portion of the purchase price goes into the business. & The entire contribution amount is used in the business. \\
\hline $\begin{array}{l}\text { Gary's basis in } \\
\text { his } \\
\text { membership } \\
\text { interest }\end{array}$ & $\begin{array}{l}\text { Gary's basis in his LLC membership interest is } \$ 400,000 \text {, } \\
\text { which is the amount he is deemed to have paid for the } \\
\text { assets, he now is deemed to have contributed to the LLC. } \\
\text { Section } 722\end{array}$ & $\begin{array}{l}\text { Gary's basis in his membership interest is } \$ 800,000 \text {, the } \\
\text { amount of cash contributed. Section } 722 \text {. }\end{array}$ \\
\hline $\begin{array}{l}\text { Steve's basis } \\
\text { in his } \\
\text { membership } \\
\text { interest }\end{array}$ & $\begin{array}{l}\text { Steve's basis is his remaining basis in the } 50 \% \text { share of the } \\
\text { company's assets not deemed sold to Gary. Section } 722\end{array}$ & $\begin{array}{l}\text { Steve's basis equals his basis in the assets that he has } \\
\text { contributed. Section } 722 \text {. }\end{array}$ \\
\hline $\begin{array}{l}\text { LLC's inside } \\
\text { basis in the } \\
\text { assets }\end{array}$ & $\begin{array}{l}\text { LLC's inside basis in the assets equals the adjusted basis } \\
\text { of the property in Steve and Gary's hands immediately } \\
\text { after the deemed asset sale to Gary. Thus, the LLC's basis } \\
\text { in the assets equals } \$ 750,000 \text {, the aggregate basis that } \\
\text { Steve ( } \$ 350,000) \text { and Gary }(\$ 400,000) \text { have in their } \\
\text { membership interests. Section } 723\end{array}$ & $\begin{array}{l}\text { LLC's inside basis in the assets equals the adjusted basis } \\
\text { of the deemed contributions from Steve. Under Section } \\
723 \text {, the tax partnership's basis in the property } \\
\text { contributed by Steve equals the adjusted basis of the } \\
\text { property to Steve prior to the contribution. The cash } \\
\text { from Gary has a basis to the tax partnership equal to its } \\
\text { face value of } \$ 800,000 \text {. }\end{array}$ \\
\hline $\begin{array}{l}\text { Members' } \\
\text { holding period } \\
\text { for } \\
\text { membership } \\
\text { interests }\end{array}$ & $\begin{array}{l}\text { Steve's holding period for the membership interest } \\
\text { includes his holding period in the capital assets and Sec } \\
1231 \text { property held by the LLC when it ceased being a } \\
\text { disregarded entity. Gary's holding period began on the } \\
\text { day following the date of purchase of the company } \\
\text { interest. Section 1223(1) }\end{array}$ & $\begin{array}{l}\text { Steve's holding period for the partnership interest } \\
\text { received includes his holding period in each of the } \\
\text { capital assets and Section } 1231 \text { property held by the LLC } \\
\text { when it ceased being a disregarded entity and became a } \\
\text { tax partnership. Gary's holding period began on the day } \\
\text { following the date that he contributed the cash and } \\
\text { became a member. Section } 1223(1)\end{array}$ \\
\hline $\begin{array}{l}\text { LLC's holding } \\
\text { period for } \\
\text { assets } \\
\text { contributed }\end{array}$ & $\begin{array}{l}\text { LLC's holding period for each of the assets is bifurcated } \\
\text { and includes both Steve's and Gary's holding period. } \\
\text { Section } 1223(2)\end{array}$ & $\begin{array}{l}\text { LLC's holding period for each of the assets deemed } \\
\text { contributed by Steve include Steve's holding period. } \\
\text { There is no bifurcation of holding period in each asset, } \\
\text { because Gary is not deemed to have contributed any } \\
\text { assets other than cash. Section } 1223(2)\end{array}$ \\
\hline
\end{tabular}




\begin{tabular}{|c|c|c|c|c|c|c|c|c|c|}
\hline & $\begin{array}{r}\text { ilver } \\
\text { A }\end{array}$ & $\begin{array}{l}\text { eak Dry } \\
\text { Balance } \\
\text { Decembe }\end{array}$ & 31, & g, LLC & & $\frac{\text { Option 1: Gary purc }}{\text { Silver Streak as }}$ & $\frac{\text { interest in }}{0,000}$ & $\frac{\text { Option 2: Gary co }}{\text { a 50\% ownershi }}$ & $\begin{array}{l}\$ 800,000 \text { for } \\
\text { in the LLC }\end{array}$ \\
\hline & & FMV & & Books & Tax Basis & Books & Tax Basis & Books & Tax Basis \\
\hline Assets & & & & & & & & & \\
\hline Cash & $\$$ & 25,000 & & $\$ 25,000$ & $\$ 25,000$ & $\$ 25,000$ & $\$ 25,000$ & $\$ 825,000$ & $\$ 825,000$ \\
\hline Equipment & & 145,000 & & 125,000 & 125,000 & 125,000 & 135,000 & 125,000 & 125,000 \\
\hline Building & & 320,000 & & 250,000 & 250,000 & 250,000 & 285,000 & 250,000 & 250,000 \\
\hline Land & & 310,000 & & 300,000 & 300,000 & 300,000 & 305,000 & 300,000 & 300,000 \\
\hline Total & $\$$ & 800,000 & & $\$ 700,000$ & $\$ 700,000$ & $\$ 700,000$ & $\$ 750,000$ & $\$ 1,500,000$ & $\$ 1,500,000$ \\
\hline & & & & & & (11\} & ב\{2\} & (24\} & (55\} \\
\hline Liabilities and Capital & & & & & & & & & \\
\hline Capital, Steve & $\$$ & 800,000 & $\$$ & 700,000 & $\$ 700,000$ & $\$ 350,000$ & $\$ 350,000$ & $\$ 700,000$ & $\$ 700,000$ \\
\hline Capital, Gary & & & & & & 350,000 & 400,000 & 800,000 & 800,000 \\
\hline Total & $\$$ & 800,000 & & $\$ 700,000$ & $\$ 700,000$ & $\$ 700,000$ & $\$ 750,000$ & $\$ 1,500,000$ & $\$ 1,500,000$ \\
\hline & & & & & & &  & & $\{6\}$ \\
\hline
\end{tabular}

$\{1\}$ Book amounts for each of the assets do not change.

\{2\} Steve has sold 1/2 of his interest in each of the assets to Gary at FMV. Therefore, 1/2 of the tax basis is Steve's old basis in each asset and 1/2 is Gary's basis (the amount he paid).

\{3\} Steve sold half of his interest in the assets of the business. Therefore, he has sold 1/2 of his basis in the business. Gain on the sale will be recognized as follows:

Total Cash $\quad$ Equipment $\quad$ Building Land

Cash Received on Sale of $1 / 2$ of his interest in assets

Basis in $1 / 2$ of his interest in assets

Gain on sale

\begin{tabular}{rrr}
$\$ 400,000$ & 12,500 & $\$ 72,500$ \\
350,000 & 12,500 & 62,500 \\
\cline { 3 - 4 }$\$ 50,000$ & - & $\$ 10,000$ \\
\hline \hline
\end{tabular}

\begin{tabular}{rr}
$\$ 160,000$ & 155,000 \\
125,000 & 150,000 \\
\hline$\$ 35,000$ & 5,000 \\
\hline \hline$\{7\}$
\end{tabular}

$\{4\}$ When Gary contributes $\$ 800,000$ to the partnership in exchange for the $50 \%$ ownership interest, nothing changes except cash increases by $\$ 800,000$ and Gary's capital account is $\$ 800,000$.

$\{5\}$ Gary has contributed cash (no property) so the tax basis of assets does not change except for cash, which is increased by the $\$ 800,000$ infusion. Gary's basis in the LLC is $\$ 800,000$.

$\{6\}$ Neither Gary or Steve recognize any gain on Gary's contribution to the LLC for a 50\% interest.

$\{7\}$ To the extent that depreciation has been claimed on these assets, there will be recaptured depreciation, resulting in ordinary income. 


\section{AUTHOR INFORMATION}

Monique Durant, JD, CPA, LLM is a tax attorney and CPA with several years of Big Four and private industry experience. She is currently an Associate Professor at Central Connecticut State University where she teaches tax courses. E-mail: Durantmon@ccsu.edu

\section{REFERENCES}

1. Revenue Ruling 99-5, 1999-1 CB 434, 1/15/1999.

2. $\quad$ IRS Publication 3402 - March 2010: LLCs Classified as Disregarded Entities.

3. Internal Revenue Code. 


\section{NOTES}

